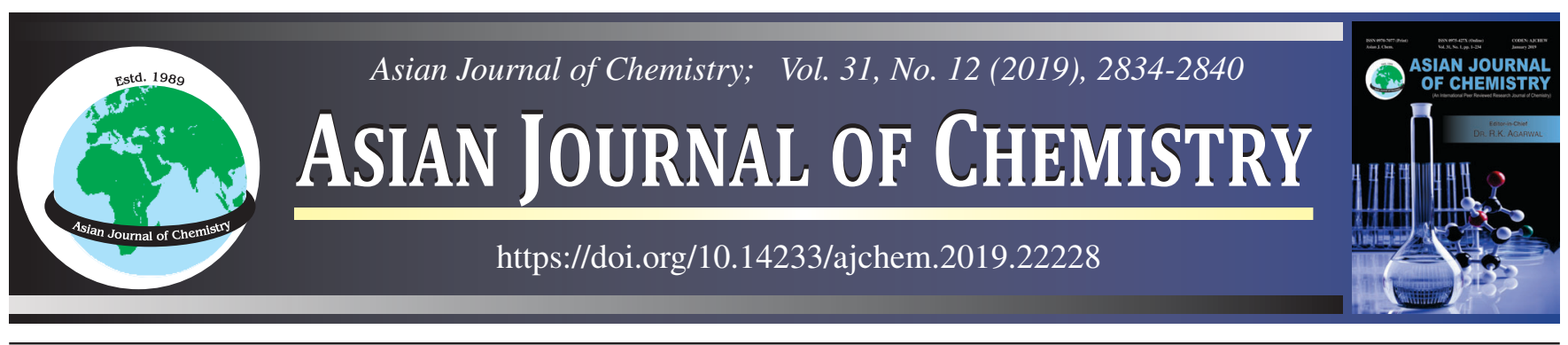

\title{
Displacement of Sodium, Potassium, Calcium, Magnesium and Improvements in a Saline Soil Treated with Organic and Chemical Amendments
}

Nallely Trejo-González ${ }^{1}$, Judith Prieto-Méndez ${ }^{1, *}$, Yolanda Marmolejo-Santillán² ${ }^{2}$ Otilio A. Acevedo-Sandoval ${ }^{1}$, Alfredo Madariaga-Navarrete ${ }^{1}$, Eliazar Aquino-Torres ${ }^{1}$, Roberto A. Canales-Flores ${ }^{2}$ and Francisco Prieto-García ${ }^{2}$

${ }^{1}$ Área Académica de Agronomía, Universidad Autónoma del Estado de Hidalgo. Carretera Pachuca-Tulancingo Km 4.5, C. P. 42076, Mineral de la Reforma, Hidalgo, México

${ }^{2}$ Área Académica de Química, Universidad Autónoma del Estado de Hidalgo. Carretera Pachuca-Tulancingo Km 4.5, C. P. 42076, Mineral de la Reforma, Hidalgo, México

*Corresponding author: E-mail: jprieto@uaeh.edu.mx

Received: 13 May 2019; Accepted: 23 July 2019; Published online: 16 November 2019;

The accumulation of salts in the soil produces conditions that affect the growth of most crops. Currently, soil amendments have been used to improve the texture and chemical \& biological reactions of the soil. The objective of this work was to simulate the transport of sodium, potassium, calcium and magnesium in columns of saline soil through the use of organic and chemical amendments. Saline soil samples of the municipality of Tlahuelilpan, Hidalgo state, Mexico were studied. Compost, vermicompost, phosphogypsum and malting barley husk were used as amendments. The results showed that the highest metal element removal was obtained with the combined treatment of vermicompost at $4 \%$ and phosphogypsum at $2 \%$ (V4FY2) (59\%). Improvements in soil physico-chemical properties were also observed. These findings indicated that the combination of organic and chemical amendments promotes the leaching of metals, (mainly sodium). Therefore, the amendments evaluated in this study can be a good alternative for the remediation and improvement of saline soils.

Keywords: Barley husk, Compost, Phosphogypsum, Saline soil, Vermicompost.

\section{INTRODUCTION}

The accumulation of salts in the soil profile produces conditions that can affect the growth of crops. The intensity of its effects are diverse and depend on the quantity and type of salts that predominate in the soil. Soil characteristics, climate, and other factors also influence crop growth [1]. Soil salinity is typical in arid and semi-arid regions in several parts of the world (primary salinization) where evapotranspiration exceeds precipitation. For this reason, irrigation is used in these regions, which induces secondary salinization of soils $[2,3]$.

The use and application of amendments in soils have become more important in recent years. By correcting the soil texture, structure problems are also adjusted (compactation or looseness) which has a positive effect on the chemical and biological reactions occurring in the soil [4]. According to Huerta [5], the elements that are most easily lost in soil are sodium, potassium, calcium and magnesium, while the soil washing does not so easily displace aluminum and hydrogen, and it remains in the soil. As a consequence of this process, the surface soil becomes acidified. The objective of this work was to simulate the transport of sodium, potassium, calcium and magnesium in columns of saline soil through the use of organic and chemical amendments.

The salts are removed from the surface layer of soil and deposited in subsurface horizons, which are usually clayey and strongly structured. This behaviour is attributed to the saturation of soil exchange complex with sodium ions that displace calcium and magnesium ions. This last represents the formation of Solonetz sodium soils. The soluble salts present in the soil are completely washed due to hydrolytic reactions that fractionate the silicates, originating a degraded soil similar to a Podzol as indicated by Ramírez [6]. On the other hand, it is reported that phosphogypsum is an excellent soil amendment over other materials used for liming since this material neutra-

This is an open access journal, and articles are distributed under the terms of the Attribution 4.0 International (CC BY 4.0) License. This license lets others distribute, remix, tweak, and build upon your work, even commercially, as long as they credit the author for the original creation. You must give appropriate credit, provide a link to the license, and indicate if changes were made. 
lizes the excess of aluminum in acid soils as well as the effects of sodium in alkaline soils [7]. The availability of $\mathrm{Al}^{3+}$ ions with the variation of soil $\mathrm{pH}$ has also been reported.

Weathering is defined as the decomposition, wear, disintegration and destruction of rocks, in response to exposure to weathering agents (e.g., water, air, temperature variations, action of organisms). The described process can be physical (disintegration of the rock into smaller pieces each time) or chemical (decomposition of the original components of the rock into different ones). Although both processes are analyzed separately, they usually act together in nature [8]. The factors that govern the chemical weathering are: (i) mechanical, (ii) original mineralogical composition, (iii) depth of materials, (iv) variations of temperature and (v) humidity. The mechanical factor is the most important since it guarantees greater exposure of the elements due to the fracturing of the source material. The fracturing process offers more exposure area due to the formation of small blocks with edges three times lower, which triples the area of exposure. The depth of materials is another critical factor; surface materials are more exposed to variations in temperature and humidity and therefore to air and organic matter. All these factors contribute to the structural stabilization of soils. On the other hand, it is reported that phosphogypsum is an excellent soil amendment over other materials used for liming since this material neutralizes the excess of aluminum in acid soils as well as the effects of sodium in alkaline soils [7]. The availability of $\mathrm{Al}^{3+}$ ions with the variation of soil $\mathrm{pH}$ has also been reported.

The use and application of amendments in soils have become more important in recent years. By correcting the soil texture, structure problems are also adjusted (compactation or looseness) which has a positive effect on the chemical and biological reactions occurring in the soil [4]. The use of livestock manure has been a practice widely used as organic soil amendments; but it has the disadvantage that the nutrients they contain can only be assimilated if they are subjected to a fermentation process where humic compounds are produced, another drawback is the loss of phosphorus and nitrogen that can occur in soils amended with livestock manure [9].

On the other hand, organic matter in the soil reduces its apparent density, increases cation exchange capacity and has a high content of humic acids. All these factors increases the capacity of moisture retention and porosity, which facilitates aeration and drainage of soil [10]. In this last aspect, it helps the formation of clay-humic complexes that directly intervene in the structural stability of soil and act as regulators of crop growth. The combination of organic and chemical amendments is new in this work and given the properties of the proposed materials is useful for the biorecovery of a saline soil and to improve the productive capacity of the soil. The objective of this work was to evaluate the effectiveness of the use of organic amendments combined with the chemical amendments that are traditionally used for the productive recovery of a sodium saline soil, for the displacement of sodium through the exchange with calcium, in a more respectful way with the environment, in the municipality of Tlahuelipan, Hidalgo, Mexico.

With the combination of the proposed amendments, it is expected that some of them will improve the productive capacity of the soil, evaluated by means of the sodium reduction and the change in physico-chemical properties of the soil, providing also greater stability to the colloids of the soil solution.

\section{EXPERIMENTAL}

Study site: The soil samples were taken in Munitepec de Madero $\left(20^{\circ} 12.47^{\prime} 28^{\prime \prime} \mathrm{N}\right.$ and $\left.99^{\circ} 20.74^{\prime} 04^{\prime \prime} \mathrm{W}\right)$ in the municipality of Tlahuelilpan in Hidalgo state. The soil samples were taken in Munitepec de Madero $\left(20^{\circ} 12.47^{\prime} 28^{\prime \prime} \mathrm{N}\right.$ and $99^{\circ} 20$. $74^{\prime} 04^{\prime \prime} \mathrm{W}$ ) in the municipality of Tlahuelilpan, . This region is located in central Mexico in Hidalgo state and has a semi-dry climate and tempered with average annual precipitation of 504 $\mathrm{mm}$ and average temperature between $14-18^{\circ} \mathrm{C}$ [11-13]. The soils of this locality are used mainly for agricultural and livestock activities. The agriculture region is $43 \%$ mechanized. The agricultural soils require irrigation that is carried out with wastewater from the valley of Mexico and its conurbations. Samples in a hectare of land divided into 4/4 randomly at 20 $\mathrm{cm}$ depth were taken. Thirteen subsamples were collected for each quarter ( 52 in total). The samples were manually cleaned, mixed, homogenized and sieved through a $2.0 \mathrm{~mm}$ mesh.

Simulation in soil columns: The simulation test in soil column was carried out in PVC columns (tubes of 3 inches in diameter and $80 \mathrm{~cm}$ in height) with a drainage system, which was used to collect the leachate from the irrigation and humidification. The drainage system consisted of a layer of cotton (2 $\mathrm{cm}$ ) followed by a layer of agrolite $(40 \mathrm{~cm})$ at the bottom of each column. The treatments were established as: Three control columns and 12 soil test columns with organic and chemical amendments were established. Fifteen columns for each trial performed in triplicate were built with a total of 45 columns.

The experimental arrangement was established as: negative control (control 1), control 2 ( $2 \%$ chemical amendment), control 3 (4\% chemical amendment) and treatments with organic amendments in proportions of 2 and $4 \%$ with and without combination with chemical amendments at $2 \%$ ratio. As a chemical amendment, only phosphogypsum was used (Table1A).

Each treatment consisted of a soil sample of $1000 \mathrm{~g}$ at a variable height between $20-26 \mathrm{~cm}$; soil samples without amendments and with amendments are shown in Table-1B. The apparent densities varied between 1.04 and $1.29 \mathrm{~g} \mathrm{~cm}^{-3}$. The calculations to establish the doses and applications of the amendments were made according to specifications reported by some researchers $[14,15]$.

For the irrigation of soil simulation columns, the average annual rainfall records for Tlahuelilpan region between 2005 and 2012 were used [12,13]. The total average yearly volume of rainfall reported for the period 2005-2012 was $639.3 \mathrm{~mm}$. No reports of evaporation and evapotranspiration were found for the study region. Therefore, it was assumed that infiltration rate $(\mathrm{I})$ is in the range of $0.015-0.018 \mathrm{~cm} \mathrm{~min}^{-1}\left(9.0-10.8 \mathrm{~mm} \mathrm{~h}^{-1}\right)$ for silty-clay soils; the rest is runoff or evaporation according to Landini et al. [16] and Valverde [17].

Because the infiltration rate in the soil is a function of its texture $[16,17]$, annual rainfall data and infiltration rate were used to determine the daily irrigation volume for each column and treatment, according to the procedures reported by Landini 
TABLE-1

\section{(A) Experimental design matrix for soil columns}

\begin{tabular}{|c|c|c|c|c|}
\hline \multirow{2}{*}{ Treatment } & \multicolumn{2}{|c|}{ Amendments } & \multirow{2}{*}{ Amendments proportion } & \multirow{2}{*}{ Sample code } \\
\hline & Organic (EO) & Chemical (FY) & & \\
\hline 1 & - & - & - & $\mathrm{NC} 1$ \\
\hline 2 & - & + & $2 \% \mathrm{PH}$ & Control 2 \\
\hline 3 & - & + & $4 \% \mathrm{PH}$ & Control 3 \\
\hline 4 & Compost & - & $2.0 \%$ & Compost 2 \\
\hline 5 & Compost & - & $4.0 \%$ & Compost 4 \\
\hline 6 & Vermicompost & - & $2.0 \%$ & Vermicompost 2 \\
\hline 7 & Vermicompost & - & $4.0 \%$ & Vermicompost 4 \\
\hline 8 & Barley husk & - & $2.0 \%$ & Barley husk 2 \\
\hline 9 & Barley husk & - & $4.0 \%$ & Barley husk 4 \\
\hline 10 & Compost & + & $2.0 \%$ & Compost $2+\mathrm{PH} 2$ \\
\hline 11 & Compost & + & $4.0 \%$ & Compost $4+\mathrm{PH} 2$ \\
\hline 12 & Vermicompost & + & $2.0 \%$ & Vermicompost $2+\mathrm{PH} 2$ \\
\hline 13 & Vermicompost & + & $4.0 \%$ & Vermicompost $4+\mathrm{PH} 2$ \\
\hline 14 & Barley husk & + & $2.0 \%$ & Barley husk $2+\mathrm{PH} 2$ \\
\hline 15 & Barley husk & + & $4.0 \%$ & Barley husk $4+\mathrm{PH} 2$ \\
\hline
\end{tabular}

(B) Experimental design matrix for the tests in soil columns

\begin{tabular}{|c|c|c|c|c|c|c|c|c|}
\hline No. & \multicolumn{2}{|c|}{ Classification } & Mas & \multicolumn{2}{|r|}{ Volume $\left(\mathrm{cm}^{3}\right)$} & \multicolumn{2}{|c|}{ Density $\left(\mathrm{g} / \mathrm{cm}^{3}\right)$} & Height $(\mathrm{cm})$ \\
\hline 1 & \multicolumn{2}{|l|}{$\mathrm{NC} 1$} & 1000 & \multicolumn{2}{|r|}{$791 \pm 2$} & \multicolumn{2}{|c|}{$1.140 \pm 0.070$} & \pm 1 \\
\hline 2 & \multicolumn{2}{|c|}{ Control 2 (PH2) } & 1020 & \multicolumn{2}{|r|}{$792 \pm 2$} & \multicolumn{2}{|c|}{$1.188 \pm 0.030$} & \pm 1 \\
\hline 3 & \multicolumn{2}{|c|}{ Control 3 (PH4) } & 1040 & \multicolumn{2}{|r|}{$867 \pm 4$} & \multicolumn{2}{|c|}{$1.200 \pm 0.030$} & \pm 1 \\
\hline 4 & \multicolumn{2}{|c|}{ Compost 2} & 1020 & \multicolumn{2}{|r|}{$817 \pm 3$} & \multicolumn{2}{|c|}{$1.148 \pm 0.030$} & \pm 1 \\
\hline 5 & \multicolumn{2}{|c|}{ Compost 4} & 1040 & \multicolumn{2}{|r|}{$839 \pm 3$} & \multicolumn{2}{|c|}{$1.160 \pm 0.030$} & \pm 1 \\
\hline 6 & \multicolumn{2}{|c|}{ Vermicompost 2} & 1020 & \multicolumn{2}{|r|}{$817 \pm 3$} & \multicolumn{2}{|c|}{$1.148 \pm 0.030$} & \pm 1 \\
\hline 7 & \multicolumn{2}{|c|}{ Vermicompost 4} & 1040 & \multicolumn{2}{|r|}{$842 \pm 3$} & \multicolumn{2}{|c|}{$1.153 \pm 0.030$} & \pm 1 \\
\hline 8 & \multicolumn{2}{|c|}{ Husk 2} & 1020 & \multicolumn{2}{|r|}{$811 \pm 3$} & \multicolumn{2}{|c|}{$1.158 \pm 0.030$} & \pm 1 \\
\hline 9 & \multicolumn{2}{|l|}{ Husk 4} & 1040 & \multicolumn{2}{|r|}{$831 \pm 3$} & \multicolumn{2}{|c|}{$1.152 \pm 0.024$} & \pm 1 \\
\hline 10 & \multicolumn{2}{|c|}{ Compost $2+\mathrm{PH} 2$} & 1040 & \multicolumn{2}{|r|}{$873 \pm 3$} & $1.191 \pm$ & & \pm 1 \\
\hline 11 & Compost 4 & & 1060 & & $849 \pm 3$ & $1.209 \pm$ & & \pm 1 \\
\hline 12 & Vermicom & $\mathrm{PH} 2$ & 1040 & & $821 \pm 3$ & $1.167 \pm$ & & \pm 1 \\
\hline 13 & Vermicom & $\mathrm{PH} 2$ & 1060 & & $851 \pm 4$ & $1.186 \pm$ & & \pm 1 \\
\hline 14 & Husk $2+\mathrm{I}$ & & 1040 & & $1015 \pm 5$ & $1.025 \pm$ & & \pm 1 \\
\hline 15 & Husk $4+\mathrm{I}$ & & 1060 & & $1019 \pm 5$ & $1.040 \pm$ & & \pm 1 \\
\hline & & Results & $\mathrm{Im}$ and $\mathrm{m}$ & m conte & tts in initial soil a & endment & & \\
\hline Initial soil & & & & & & & & \\
\hline Amendments & $\mathrm{mg} / \mathrm{Kg}$ & SEM & $\mathrm{mg} / \mathrm{Kg}$ & SEM & $\mathrm{mg} / \mathrm{Kg}$ & SEM & $\mathrm{mg} / \mathrm{Kg}$ & SEM \\
\hline Soil & 947.7 & 12.87 & 297.7 & 13.55 & 679.6 & 12.09 & 452.4 & 9.84 \\
\hline Compost & 230.0 & 1.73 & 22.30 & 0.83 & 95.0 & 2.45 & 84.0 & 0.63 \\
\hline Vermicompost & 200.0 & 0.76 & 79.50 & 0.79 & 133.6 & 2.87 & 121.0 & 0.78 \\
\hline Barley husk & 120.0 & 6.72 & 75.30 & 1.44 & 330.0 & 11.08 & 90.0 & 2.16 \\
\hline Phosphogypsum & 15.0 & 0.55 & 18.0 & 0.50 & 21950.0 & 23.67 & 2200.0 & 21.3 \\
\hline
\end{tabular}

PH2: Phosphogypsum $2 \%$; PH4: Phosphogypsum $4 \%$; SEM: Standard error of the mean; NC: Negative control

et al. [16] and World Wildlife Find (WWF) [18]. Irrigation was carried out weekly, and the leachates were collected $24 \mathrm{~h}$ later.

Tests and analysis: Irrigations were carried out for 11 weeks and the respective leachates were collected. For each treatment, the following analyzes were carried out: (i) texture of the soil samples by Bouyoucus method [19]; (ii) real and apparent density of initial soil and all treatments completed after 11 weeks according to the AS-03 and AS-04 methods, respectively [19]; (iii) moisture content according to the AS05 method [19]; (iv) determination of humic acids and fulvic acid by sequential extractions [20].

The metal analysis was carried out by inductive coupling plasma spectroscopy with a Perkin-Elmer spectrophotometer (Optima 8000), using Ar for the generation of plasma. For ICPS readings, standards $\left(0-20 \mathrm{mg} \mathrm{L}^{-1}\right)$ were prepared to obtain the calibration curves for each study metal (sodium, potassium, calcium and magnesium). Leachates $(50 \mathrm{~mL}$ per treatment) were collected and added $5 \mathrm{~mL}$ of concentrated $\mathrm{HNO}_{3}$ gauged to $100 \mathrm{~mL}$ and kept under refrigeration.

\section{RESULTS AND DISCUSSION}

Behaviour of sodium in leachates: Fig. 1 shows the behaviour of sodium leached by irrigation (7 irrigations in total). It can be seen that from the $5^{\text {th }}, 6^{\text {th }}$ and $7^{\text {th }}$ irrigations, sodium leached remains constant. The highest sodium removal was observed in the first three irrigations. With the treatment V4PH2 (vermicompost with phosphogypsum at $2 \%$ ) was obta-ined the most top sodium removal. Table-1C shows the initial results of sodium, potassium, calcium and magnesium in the soil and the amendments used. It can be seen the high sodium content in the initial soil (saline soil), which presented a sodium adsorption ratio (SAR) of 39.83 (moderate risk of sodicity) [6]. 


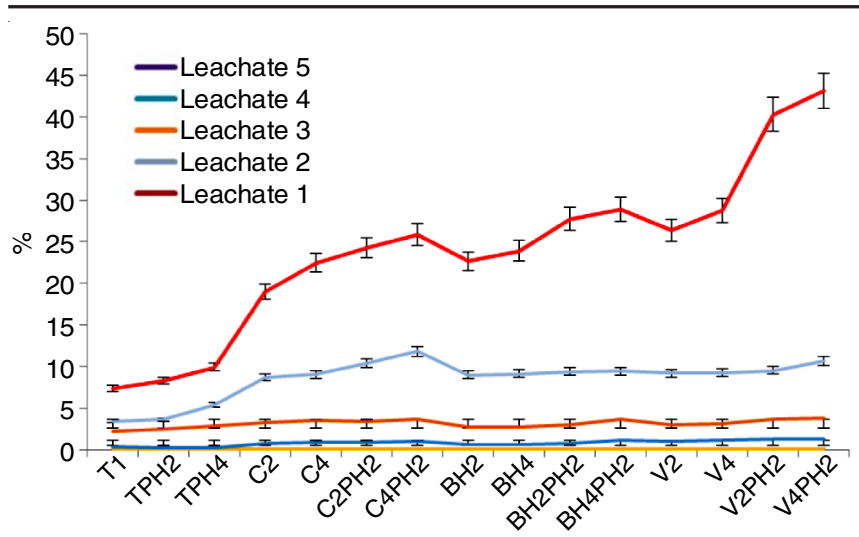

Fig. 1. Sodium behavior in leachates. The error bars indicate the standard error of the mean (SEM)

Fig. 2 showed that the control 1 (T1) presented $13 \%$ of sodium reduction (washing) compared with the initial content. Decreases of $14.6 \%(2 \%)$ and $18.4 \%(4 \%)$ for sodium concentration were observed with the gypsum treatment (chemical amendment). In contrast, organic amendments compost and barley husk at 2 and $4 \%$, doubled the decrease in soil sodium (35-36\%). This last treatment, used in combination with $2 \%$ of the chemical amendment, reached three times the treatment effectiveness (40-43\%). The best soil sodium removal (59\%) resulted from the combination of vermicompost $(\mathrm{V})$ with FY. This last result is consistent with the report of Manzano et al. [21], who worked with a saline-sodic soil with a conductivity of $7.75 \mathrm{dS} \mathrm{m}^{-1}$ and $1432 \mathrm{mg} \mathrm{Na} \mathrm{kg}^{-1}$ (1.5 times higher for the same parameters reported in this study). Cattle manure and gypsum $\left(\mathrm{CaSO}_{4}\right)$ in different proportions were used as soil amendments. With this treatment, they managed to reduce the conductivity and sodium contents by 27 and $18 \%$, respectively.

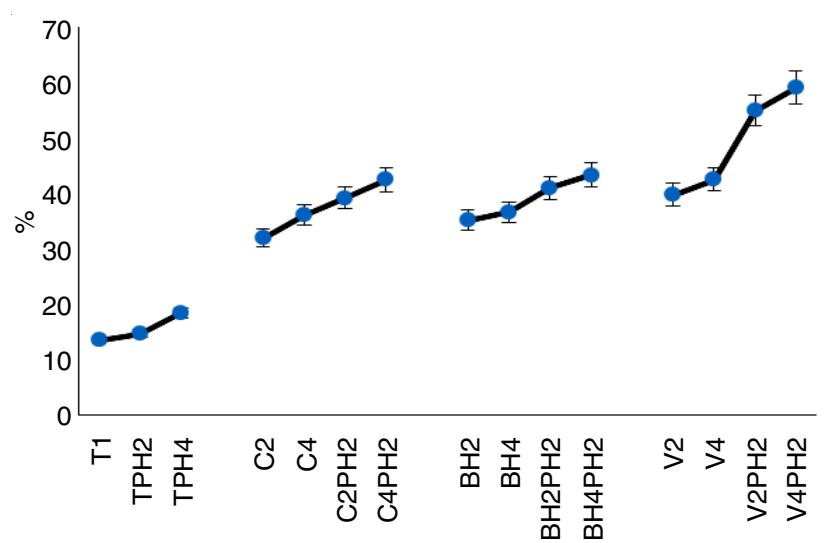

Fig. 2. Percentages of final removal of sodium with different treatments. The error bars indicate the SEM

Graphically, the final behaviour of percentage of sodium removed can be appreciated. It is observed that for all the treatments the addition of chemical amendment (phosphogypsum) leads to a slight improvement, but the application of organic amendments significantly improves the percentages of removal. The following proposed equation explains the exchange mechanism, which explain how calcium exchange leaches sodium.

$$
\mathrm{Na}_{2}-\text { Micelle }+\mathrm{CaSO}_{4(\mathrm{ac})} \longrightarrow \mathrm{Ca}=\text { Micelle }+\mathrm{Na}_{2} \mathrm{SO}_{4(\text { (ac) }}
$$

It can be seen that with the application of compost $(\mathrm{C})$ and barley husk $(\mathrm{Ca})$, similar results are obtained. The same beha- viour occurs with the vermicompost $(\mathrm{V})$ for the removal of initial soil sodium but without the addition of chemical amendment (phosphogypsum). When vermicompost is combined in 2 and $4 \%$ with phosphogypsum in $2 \%$, effectiveness close to $60 \%$ is achieved.

Potassium behaviour in leachates: Fig. 3 shows that the percentages of potassium removal were low. In contrast, the higher removal percentages of this metal were obtained in the controls with phosphogypsum (TPH), reaching values between $1.9-2.3 \%$ of potassium leached. It was observed that barley husk $(\mathrm{Ca})$ leached less potassium, as well as compost (C) and vermicompost $(\mathrm{V})$ that behaved similarly. This finding is consistent with that reported by Hernández [22], who used duckweed (Lerma spp.) as an organic amendment, obtaining low potassium leaching.

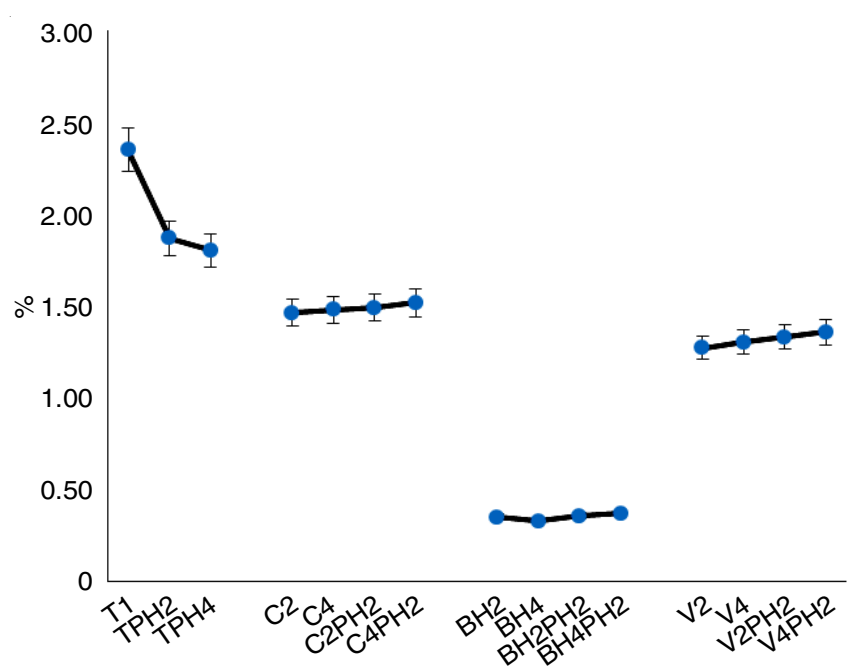

Fig. 3. Percentages of final removal of potassium with different treatments. The error bars indicate the SEM

Behaviour of calcium in leachates: The results obtained with gypsum (phosphogypsum) treatments in saline-sodic and sodic soils shown that calcium exchange replaces the sodium adsorbed in the soil complex according to the proposed reaction mechanism [22]. As a consequence of moderate solubility of gypsum $\left(2.5 \mathrm{~g} \mathrm{~L}^{-1}\right)$ increases in the calcium content of soil and the leachates were observed, which is attributed to the fact that part of $\mathrm{CaSO}_{4} \cdot 2 \mathrm{H}_{2} \mathrm{O}$ (phosphogypsum), will provide $\mathrm{Ca}^{2+}$ ions that will also be in the leachates.

In Fig. 4, it is observed that the proportions of calcium in leachates are between 28 and $53 \%$, excelling in those experiments with the presence of phosphogypsum (TPH). This behaviour is since the micellar part of organic amendments (colloids in suspension) retain part of calcium and does not allow its leaching, which enriches the soil with calcium and increases the stability of organic matter. Phosphogypsum provides calcium which is required to flocculate clays and improve the texture of soils [22], favouring root growth, aeration and movement of water through the soil. Besides, calcium helps to reduce the soil $\mathrm{pH}$ by forming and precipitating carbonates and sometimes by forming complex salts with ammonium ions $\left(\mathrm{NH}_{4}{ }^{+}\right)$which help to fix nitrogen in soils [23].

Magnesium behaviour in leachates: Magnesium ion has dispersive properties and can cause adverse effects on the phys- 


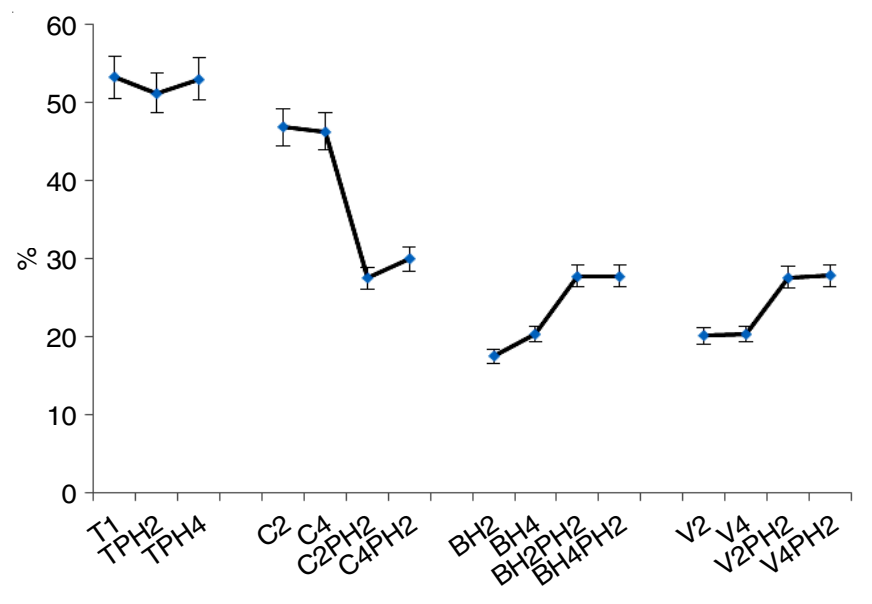

Fig. 4. Percentages of final removal of calcium with different treatments. The error bars indicate the SEM

ical properties of soil showing a similar behaviour to the interchangeable $\mathrm{Na}^{+}$. Soils where magnesium accumulates in the form of inorganic salts, mainly magnesium sulfate and magnesium chloride, are known as Solonetz (Fig. 5).

Increases in magnesium in soil and leachate were observed as a product of the moderate solubility of the gypsum $(2.5 \mathrm{~g}$ $\mathrm{L}^{-1}$ ) and by $\mathrm{Mg}^{2+}$ contents that can be contributed by phosphogypsum. On the other hand, the importance of calcium as a nutrient for the growth of plants can not be separated from its role as a soil neutralizer and its relationship with other cations such as potassium and magnesium [24]. In it, the importance of $\mathrm{Mg}^{2+}$ in soil is revealed. Magnesium causes a decrease in the percentage of stable aggregates and the amount of clay that acts as a cementing agent. This element also negatively affects aggregates porosity [25].

Solonetz soils, as analyzed in present study, are found in areas with a continental semi-arid climate (dry summers and an annual rainfall of $400-500 \mathrm{~mm}$ ). These soils are also present in tropical and subtropical arid regions.

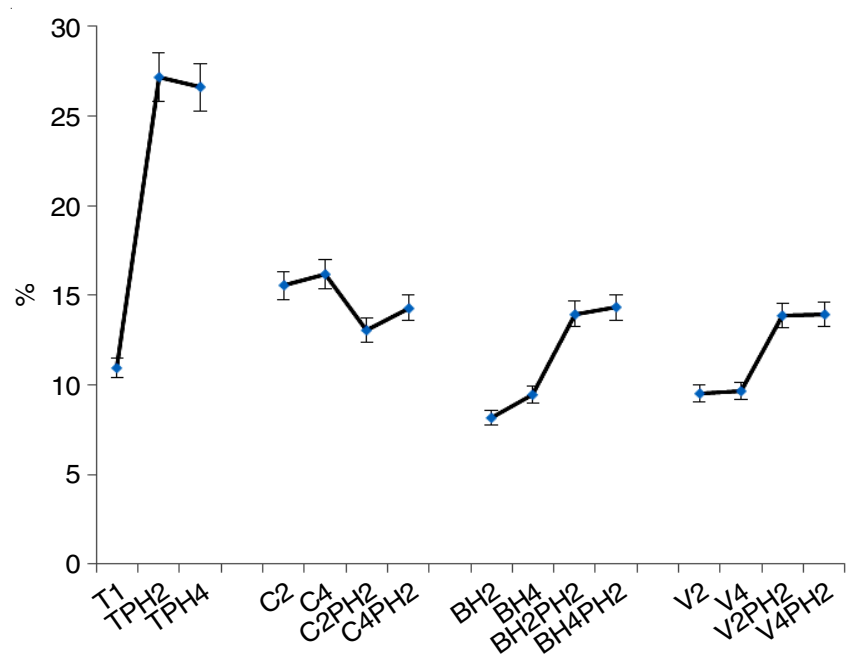

Fig. 5. Percentages of final removal of magnesium with different treatments. The error bars indicate the SEM

The improvement of Solonetz has two main advantages: (i) improvement of the porosity of superficial or subsurface soil, and (ii) decrease in the percentage of exchangeable sodium.

Most attempts for soil recovery begin with the incorporation of gypsum or calcium chloride. When the lime or gypsum is shallow, deep ploughing (mixing the subsurface soil, which contains carbonate or gypsum, with the surface soil) can make costly amendments unnecessary. Traditional strategies for soil recovery begin with the planting of a sodium resistant crop, such as Rhodes grass, to gradually improve soil permeability. Once the soil pore system is in operation, sodium ions are carefully washed from the soil with water rich in calcium. It should be mentioned that the use of relatively pure water must be avoided since the dispersion problem worsens.

Real and apparent densities, texture and humidity in treated soils: Table- 2 shows the initial obtained values in the soil sample and those obtained after 11 weeks of the treatments.

TABLE-2

CHARACTERIZATION OF INITIAL SOILS AND SOILS AFTER THE TREATMENTS WITH AMENDMENTS

\begin{tabular}{|c|c|c|c|c|c|c|c|c|c|}
\hline \multirow[b]{2}{*}{ Samples } & \multirow{2}{*}{$\begin{array}{l}\text { Density } \\
\text { real } \\
\left(\mathrm{g} / \mathrm{cm}^{3}\right)\end{array}$} & \multirow{2}{*}{$\begin{array}{l}\text { Density } \\
\text { apparent } \\
\left(\mathrm{g} / \mathrm{cm}^{3}\right)\end{array}$} & \multirow{2}{*}{$\begin{array}{l}\text { Humidity } \\
(\%)\end{array}$} & \multicolumn{4}{|c|}{ Texture } & \multirow{2}{*}{$\begin{array}{c}\text { Fulvic } \\
\text { acid }(\%)\end{array}$} & \multirow{2}{*}{$\begin{array}{c}\text { Humic } \\
\text { acid }(\%)\end{array}$} \\
\hline & & & & $\begin{array}{c}\text { Sand } \\
(\%)\end{array}$ & $\begin{array}{l}\text { Silt } \\
(\%)\end{array}$ & $\begin{array}{l}\text { Clay } \\
(\%)\end{array}$ & Type & & \\
\hline Initial soil & $2.47(0.11)$ & $1.14(0.07)$ & $5.34(0.41)$ & $58 a$ & $32 a$ & $10 \mathrm{a}$ & Sandy loam & $1,61(0.22)$ & $0,80(0.02)$ \\
\hline Control 1 & $2.46(0,12)$ & $1.14(0,07)$ & $6,12(0.25)$ & $59 a$ & $31 \mathrm{a}$ & $10 \mathrm{a}$ & Sandy loam & $1,49(0.16)$ & $0,83(0.02)$ \\
\hline Control 2 (NCPH2) & $2,12(0.08)$ & $1,10(0.05)$ & $7,15(0.22)$ & $56 \mathrm{~b}$ & $34 b$ & $10 \mathrm{a}$ & Sandy loam & $1,38(0.17)$ & $0,78(0.02)$ \\
\hline Control 3 (NCPH4) & $2,16(0.07)$ & $1,09(0.05)$ & $6,56(0.18)$ & $56 \mathrm{~b}$ & $34 b$ & $9 a$ & Sandy loam & $1,33(0.09)$ & $0,74(0.01)$ \\
\hline Compost 2 & $2,12(0.06)$ & $1,14(0.06)$ & $6,39(0.15)$ & $53 c$ & $35 b$ & $10 \mathrm{a}$ & Sandy loam & $2,08(0.11)$ & $1,42(0.04)$ \\
\hline Compost 4 & $2,10(0.07)$ & $1,13(0.06)$ & $7,59(0.21)$ & $54 \mathrm{c}$ & $34 b$ & $12 \mathrm{~b}$ & Sandy loam & $2,42(0.14)$ & $1,36(0.03)$ \\
\hline Vermicompost 2 & $2,16(0.07)$ & $1,12(0.05)$ & $6,80(0.20)$ & $54 \mathrm{c}$ & $35 b$ & $11 \mathrm{~b}$ & Sandy loam & $3,02(0.15)$ & $2,06(0.05)$ \\
\hline Vermicompost 4 & $2,21(0.08)$ & $1,20(0.06)$ & $6,39(0.19)$ & $53 c$ & $35 b$ & $12 \mathrm{~b}$ & Sandy loam & $3,24(0.20)$ & $2,16(0.06)$ \\
\hline Barley husk 2 & $2,18(0.08)$ & $1,13(0.05)$ & $6,16(0.13)$ & $56 \mathrm{~b}$ & $33 c$ & $10 \mathrm{a}$ & Sandy loam & $1,78(0.16)$ & $1,50(0.04)$ \\
\hline Barley husk 4 & $2,21(0.04)$ & $1,13(0.06)$ & $6,60(0.18)$ & $57 \mathrm{~b}$ & $32 \mathrm{a}$ & $11 \mathrm{~b}$ & Sandy loam & $1,80(0.12)$ & $1,50(0.05)$ \\
\hline Compos $2+\mathrm{PH} 2$ & $2,03(0.05)$ & $1,10(0.03)$ & $8,21(0.22)$ & $53 c$ & $35 \mathrm{~b}$ & $12 \mathrm{~b}$ & Sandy loam & $1,88(0.12)$ & $1,54(0.04)$ \\
\hline Compos $4+\mathrm{PH} 2$ & $2,17(0.07)$ & $1,11(0.04)$ & $6,84(0.19)$ & $54 \mathrm{c}$ & $33 \mathrm{c}$ & $13 \mathrm{c}$ & Sandy loam & $1,99(0.13)$ & $1,46(0.04)$ \\
\hline Vermic $2+\mathrm{PH} 2$ & $2,00(0.05)$ & $1,09(0.04)$ & $5,74(0.17)$ & $53 c$ & $35 b$ & $12 \mathrm{~b}$ & Sandy loam & $3,04(0.21)$ & $2,08(0.06)$ \\
\hline Vermic $4+\mathrm{PH} 2$ & $2,13(0.07)$ & $1,15(0.06)$ & $6,01(0.15)$ & $54 \mathrm{c}$ & $35 b$ & $13 \mathrm{c}$ & Sandy loam & $3,21(0.22)$ & $2,16(0.06)$ \\
\hline Barley husk $2+\mathrm{PH} 2$ & $2,11(0.06)$ & $1,15(0.05)$ & $6,24(0.17)$ & $53 c$ & $36 \mathrm{~d}$ & $11 \mathrm{~b}$ & Sandy loam & $1,70(0.12)$ & $1,48(0.04)$ \\
\hline Barley husk $4+\mathrm{PH} 2$ & $2,16(0.06)$ & $1,13(0.05)$ & $6,74(0.18)$ & $54 \mathrm{c}$ & $34 b$ & $12 \mathrm{~b}$ & Sandy loam & $1,75(0.12)$ & $1,50(0.05)$ \\
\hline $\begin{array}{l}\text { Average with } \\
\text { treatments }\end{array}$ & $2,13(0.08)$ & $1,13(0.06)$ & $6,64(0.20)$ & 53 & 35 & 12 & $\begin{array}{c}\text { Speed Infilt. = } \\
20-30 \mathrm{~mm} / \mathrm{h} \mathrm{(*)}\end{array}$ & $1.76(0.14)$ & $1.46(0.04)$ \\
\hline
\end{tabular}

(*) By estimate as reported [Ref. 26]; Different letters in columns indicate significant differences $(\mathrm{p}<0.05)$; Standard error of the mean appears in parentheses; PH2: phosphogypsum $2 \%$. 
Control 1 is also shown and corresponds to the initial soil without amendments after 11 weeks with the several irrigations.

The textural classification as sandy-loam soil was not modified; however, a tendency to reduce the percentages of sand (from $58 \%$ to $53.5 \%$ on average) was observed with moderate increases in the percentages of Limo (from $32 \%$ to $35 \%$ on average) and the percentages of clay (from $10 \%$ to $12 \%$ on average). Therefore, it is established that the organic amendments also improve the soil texture, which is consistent with the findings reported by Delgado [27].

With an 11-week treatment, it is difficult to appreciate a significant textural change and structural stabilization. Thus, the structural stability is the resistance of grains to disintegrate in humid conditions and defines the state of aggregation of mineral or organic particles of the soil. This soil parameter depends on the arrangement and adhesion of the smaller particles to form aggregates [28]. These approaches are consistent with the results of the apparent and real densities, where no significant variations were observed despite the different treatments.

Regarding moisture contents, a moderate increase in water retention was observed (Table-2), after the treatments with all the amendments; the increments were 1.2 times greater than those obtained for the initial soil moisture. In relation to humic substances, the results were consistent with what was affirmed by Adani et al. [29] and Abril et al. [30], since more massive doses of amendments do not always cause an increase in the humified fractions of soil (proportion of $\mathrm{AF}$ and $\mathrm{AH}$ is modified).

These results also indicate that the likelihood increases of total organic matter $(\mathrm{OM})$ are mainly due to the non-humid fraction (NHF), which is consistent with that reported by Lejon et al. [31], since the application of organic amendments increases the fractions labile more than those obtained with AH. Nonhumic substances (NHS) are well-known compounds such as amino acids, proteins, carbohydrates, lipids, lignin, nucleic acids, hormones, pigments and a variety of organic acids.

\section{Conclusion}

Sodium is leached only by the action of water and $13 \%$ of the initial total is removed. However, this percentage increases with the chemical amendment that provides $\mathrm{Ca}^{2+}$ ions that improve the exchange. When organic loads are applied (compost, barley husk and vermicompost), the removal of initial sodium is doubled upto 30-35\% and, in combination with the calcium of phosphogypsum the removal increases upto 39-59 $\%$. The exchange mechanism of sodium with calcium provided, indicates that as organic loads are added, the micellar phase increases (colloids in soil solution) and exchange is favoured. Only with chemical amendments (phosphogypsum) calcium leaches between 51-53\%; presence of organic amendments, by providing stability to colloids of soil solution (an increase of micellar phase), retains more significant amounts of calcium, which decreases the elimination of this element around 27-30 $\%$. In the case of potassium, there is no great exchange, which is due to its small amount in the initial soil and its crystalline phase, which is not very lixiviated. This element was removed between 0.3-2.3\%; chemical and organic amendments did not improve notably the elimination mechanism. Regarding magnesium, a behaviour similar to that of calcium was observed. With the use of phosphogypsum this element was reduced between $11-27 \%$ and with organic loads, it is reduced by around 8-13\%. The textural classification of sandy-loam soil was maintained. There was a tendency to reduce the percentages of sand with moderate increases in the percentages of silt and clays. From this finding, it is established that organic amendments also favour the texture of soil.

With a time of 11 weeks of treatment, it is difficult to observe a significant textural change and structural stabilization. Neither can significant differences were found in the apparent and real densities for the same reasons. It was found that not always higher doses of organic amendments increase the humified fractions of soil, although the proportion of fulvic acid and humic acid is modified differentially.

\section{CONFLICT OF INTEREST}

The authors declare that there is no conflict of interests regarding the publication of this article.

\section{REFERENCES}

1. S. Busoms, J. Teres, X.-Y. Huang, K. Bomblies, J. Danku, A. Douglas, D. Weigel, C. Poschenrieder and D.E. Salt, Plant Physiol., 168, 915 (2015); https://doi.org/10.1104/pp.15.00427.

2. C.A. Wada, K. Burnett and J.J. Gurdak, Sustain. Agric. Res., 5, 76 (2016); https://doi.org/10.5539/sar.v5n3p76.

3. L. Giménez, M. Petillo, P. Paredes and L. Pereira, Water, 8, 309 (2016); https://doi.org/10.3390/w8070309.

4. A. Rodríguez-Vila, V. Asensio, R. Forján and E.F. Covelo, Spanish J. Soil Sci., 5, 130 (2015); https://doi.org/10.3232/SJSS.2015.V5.N2.03.

5. J. Huerta, Professional Thesis, Mejoradores potenciales de $\mathrm{pH}$ para suelos ácidos y alcalinos, Flooring Department, Autonomous University of Chapingo, p. 13 (2011) (In Spanish).

6. P.M. Ramírez, Engineering Thesis, Condiciones de salinidad y recuperación de los suelos de la cancha pública de golf San Antonio, Lima, Perú, National Agrarian University La Molina, Lima, Peru, p. 10 (2016).

7. M. Mesic, L. Brezinsèak, Z. Zgorelec, A. Perèin, I. Sestak, D. Bilandzija, M. Trdenic and H. Lisac, Agric. Conspectus Scient. cus., 81, 7 (2016).

8. F.A. Núñez, Invest. Geog. Bol. Inst. Geografía, 2017, 3 (2017).

9. K. Wang, H. Mao and X. Li, Bioresour. Technol., 249, 527 (2018); https://doi.org/10.1016/j.biortech.2017.10.034.

10. K. Hashemimajd, M. Kalbasi, A. Golchin and H. Shariatmandari, J. Plant Nutr., 27, 1107 (2004); https://doi.org/10.1081/PLN-120037538.

11. M.M. Acosta Álvarez, Bachelor Thesis in Biology, Determinación de metales pesados en suelos agrícolas del Valle del Mezquital, Hidalgo. Universidad Autónoma del Estado de Hidalgo, pp. 50-59 (2007) (In Spanish).

12. Inegi, National Institute of Statistic and Geography, Hidalgo Statistical and Geographic Yearbook 2013 pp. 35-45 (2014).

13. SMN-CONAGUA, National Metereological Service; National Water Comission (2016).

14. F. Lobo and R.E. Espinoza, Copeia, 2004, 850 (2004); https://doi.org/10.1643/CH-03-241R1.

15. IFA, International Association of the Fertilizer Industry. Fertilizers and their Uses, IFA: France, edn 4, pp. 44-51 (2002).

16. A.M. Landini, D. Martínez, H. Días, E. Soza, D. Agnes and C. Sainato, C. Suelo (Argentina), 25, 123 (2007).

17. L. Valverde, Bol. Sanid. Veg., Plagas, 33, 163 (2007).

18. WWF, World Wildlife Fund, Annual Review Conservation Achievements So Far (2009).

19. Official Mexican Standard NOM-021-RECNAT-2000. Specifications of Fertility, Salinity and Classification of Soils. Studies, Sampling and Analysis (2000).

20. M.D. Rodríguez-Torres, J. Venegas-Gonzalez, M.V. Angoa-Perez and J.L. Montañez-Sato, Bioagro, 21, 183 (2009). 
21. J.I. Manzano Banda, P. Rivera Ortiz, F. Briones Encinia and C. Zamora Tovar, Terra Latinoamericana, 32, 211 (2014).

22. J.A. Hernández, Doctoral Thesis, Biorecuperation of Saline Soils using Organic Materials, Polytechnic University of Madrid, Spain, p. 39 (2011).

23. M. Vázquez and A. Pagani, eds.: H. Echeverría and F. García, Calcium and Magnesium from the Soil. Fertilization Management and Amendments. In: Soil Fertility and Crop Fertilization, INTA, Chap. 11, pp. 317-356 (2015).

24. W. Guo, H. Nazim, Z. Liang and D. Yang, Crop J., 4, 83 (2016); https://doi.org/10.1016/j.cj.2015.11.003.

25. J.A. Villazón Gómez, G. Martín Gutiérrez and Y. Cobo Vidal, Cent. Agríc., 44, 56 (2017).

26. M.A. Velásquez -Valle, I. Sánchez-Cohen, R. Gutiérrez-Luna, J.A. Muñoz-Villalobos and H. Macias-Rodríguez, Rev. Chapingo Ser. Zonas Áridas, 13, 47 (2014);

https://doi.org/10.5154/r.rchsza.2013.10.004.
27. M.A. Delgado-Londoño, Lámpsakos, 17, 77 (2017); https://doi.org/10.21501/21454086.1907.

28. M.L. Medina Guerrero, G.A. Zanor and J.A. Suárez-Mendoza, Jóvenes en la Ciencia, 1, 89 (2015).

29. F. Adani, P. Genevini, F. Tambone and E. Montoneri, Chemosphere, 65, 1414 (2006); https://doi.org/10.1016/j.chemosphere.2006.03.070.

30. A. Abril, L. Noe and M.F. Filippini, Rev. Investig. Agropecu, 40, 83 (2014).

31. D.P.H. Lejon, J. Sebastia, I. Lamy, R. Chaussod and L. Ranjard, Microb. Ecol., 53, 650 (2007); https://doi.org/10.1007/s00248-006-9145-6. 